\title{
Considerations of How to Study Learning Processes when Students use GIS as an Instrument for Developing Spatial Thinking Skills
}

Madsen, Lene Møller; Rump, Camilla Østerberg

Published in:

Journal of Geography in Higher Education

DOI:

$10.1080 / 03098265.2011 .576336$

Publication date:

2012

Document version

Early version, also known as pre-print

Citation for published version (APA):

Madsen, L. M., \& Rump, C. Ø. (2012). Considerations of How to Study Learning Processes when Students use GIS as an Instrument for Developing Spatial Thinking Skills. Journal of Geography in Higher Education, 36(01), 97-116. [Selected for publication as Chapter 13 in Haigh, M., Cotton, D. and Hall, T. (eds.) (2016): Pedagogic Research in Geography Higher Education, Routledge.]. https://doi.org/10.1080/03098265.2011.576336 
This article was downloaded by: [Copenhagen University Library] On: 23 May 2012, At: 00:48

Publisher: Routledge

Informa Ltd Registered in England and Wales Registered Number: 1072954 Registered office: Mortimer House, 37-41 Mortimer Street, London W1T 3J H, UK

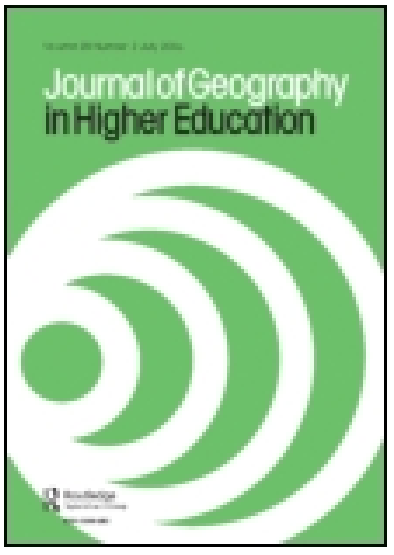

\title{
J ournal of Geography in Higher Education
}

Publication details, including instructions for authors and subscription information:

http:// www. tandfonline.com/loi/ cjgh20

\section{Considerations of How to Study Learning Processes when Students use GIS as an Instrument for Developing Spatial Thinking Skills}

\author{
Lene Møller Madsen ${ }^{a} \&$ Camilla Rump ${ }^{a}$ \\ a Department of Science Education, University of Copenhagen, \\ Denmark
}

Available online: 07 Nov 2011

To cite this article: Lene Møller Madsen \& Camilla Rump (2012): Considerations of How to Study Learning Processes when Students use GIS as an Instrument for Developing Spatial Thinking Skills, J ournal of Geography in Higher Education, 36:1, 97-116

To link to this article: http:// dx.doi.org/ 10.1080/ 03098265.2011.576336

\section{PLEASE SCROLL DOWN FOR ARTICLE}

Full terms and conditions of use: http://www.tandfonline.com/page/terms-and-conditions

This article may be used for research, teaching, and private study purposes. Any substantial or systematic reproduction, redistribution, reselling, loan, sub-licensing, systematic supply, or distribution in any form to anyone is expressly forbidden.

The publisher does not give any warranty express or implied or make any representation that the contents will be complete or accurate or up to date. The accuracy of any instructions, formulae, and drug doses should be independently verified with primary sources. The publisher shall not be liable for any loss, actions, claims, proceedings, demand, or costs or damages whatsoever or howsoever caused arising directly or indirectly in connection with or arising out of the use of this material. 


\title{
Considerations of How to Study Learning Processes when Students use GIS as an Instrument for Developing Spatial Thinking Skills
}

\author{
LENE MØLLER MADSEN \& CAMILLA RUMP \\ Department of Science Education, University of Copenhagen, Denmark
}

\begin{abstract}
Within the last 30 years, geographical information systems (GIS) have been used increasingly in the training of geographers. On the basis of the philosophy of technology and instrumental genesis, we sketch how the use of instruments interacts with learning processes and outline how this can be studied. We empirically analyse students' learning processes and the influences of teaching practice in an introductory course in GIS. We show that students have different strategies for creating their personal instrument for spatial thinking and how teaching interacts with the students' learning processes. Finally, we discuss how GIS may gradually alter future professional development of geographers.
\end{abstract}

KEY WoRDS: Spatial thinking, GIS, learning processes, teaching orchestration, professional outlook

\section{Introduction}

Within the last 30 years, geographical information systems (GIS) have been introduced and integrated into the curricula of geographers in many countries. Different types and levels of GIS courses have been included in a wide number of geography university curricula and at various levels of lower and upper secondary schools. Today, GIS can be said to be an important part of the training of geographers and an integrated part of thinking about geography in the wider public sphere (Catling \& Taylor, 2007).

There are many challenges involved in including GIS in the geography curricula at different educational levels; for example the technical impediments that stem from the complexity of software, the lack of experienced teachers and unclear curriculum demands (Lloyd, 2001; Rød et al., 2010). Different examples have been given on how to integrate GIS in relation to specific geography subjects such as heritage landscapes (SummerbyMurray, 2001), different teaching methods such as problem-based learning (Drennon, 2005), self-learning modules (Zerger et al., 2002) and the use of a multimedia classroom (Deadman et al., 2000).

Correspondence Address: Lene Møller Madsen, Department of Science Education, University of Copenhagen, Østre Voldgade 3, DK-1350 Copenhagen K, Denmark. Email: 1mmadsen@ind.ku.dk

ISSN 0309-8265 Print/1466-1845 Online/12/010097-20 (C) 2012 Taylor \& Francis

http://dx.doi.org/10.1080/03098265.2011.576336 
GIS have been linked to the concept of spatial thinking in relation to students' development of spatial abilities. This has been done by claiming that GIS can develop students abilities to solve spatial problems, reason spatially and improve their map-reading skills (e.g. Albert \& Golledge, 1996; Hall-Wallace \& McAuliffe, 2002), and it has recently been shown empirically that GIS learning improves learners' spatial thinking ability (Lee $\&$ Bednarz, 2009). At the curriculum level, support systems such as GIS have also been linked to the goal of developing competent spatial thinkers, most noticeably in the publication Learning to Think Spatially by the US National Academy of Sciences (National Research Council, 2006). Here, it is stated that

GIS are only one of a suite of support systems, high and low tech in nature, that must be brought to bear in fostering an understanding for and appreciation of spatial thinking. All students deserve and need the opportunity to be challenged, to be supported and to become critical spatial thinkers (National Research Council, 2006, p. 241).

This has fostered optimism among geographers as spatial thinking is now seen as an integrator and facilitator for problem solving and a missing link across the curriculum in a wider educational sphere and not only by geographers for whom spatial thinking has long been a central issue (Catling \& Taylor, 2007). Furthermore, it gives spatial support systems a prominent status as stated by Sarah Bednarz: "Spatial thinking, supported by geospatial technologies, can — and should—form the foundation of innovative geography curriculum" (Bednarz, 2007, p. 13). In Learning to Think Spatially, discussion of the support system has also been given focus. In reflecting on using GIS to think spatially, Lyn Malone concludes: "The power of this learning experience is the result of an inquiry process that is supported by a tool (in this case GIS)" (National Research Council, 2006, p. 241).

Following this, GIS have been and are often still seen as a technical expansion of the toolbox of geographers. However, along the way this toolbox has been more and more tightly linked to the educational request of creating competent spatial thinkers within the educational system. There is no clear consensus about a definition of spatial thinking within research communities, but this has not hindered educational discussions of how to foster spatial literacy. This discrepancy is not our concern in this paper. Our interest is in learning processes involving GIS as an instrument for learning and leading students to become spatial thinkers. We do not claim, however, that GIS should be the only way for geographers to become competent spatial thinkers. There indeed exist and should exist a wide variety of ways and instruments for geographers to foster their spatial abilities, spatial reasoning, spatial cognition, spatial intelligence and spatial concepts making. Here, we just mention one other central instrument: maps that have been extensively discussed in MacEachren (2004). We are, nevertheless, in this paper, only interested in the relation between GIS and spatial thinking.

Using an instrument in learning processes affects more than the technical expansion it involves - it affects not only how we learn but also potentially what we learn (Verbeek, 2000). Important questions in relation to GIS and spatial thinking are the following: How do students learn to see through the instrument of GIS and understand the spatiality it represents? and Does teaching practice influence this learning process? These are issues addressed in this paper. Furthermore, we hope to initiate a debate on how GIS may alter the ways we as geographers think spatially because using an instrument is not neutral, but 
influences the way students perceive and understand geographical issues. Thereby it may in the long run potentially modify the professional outlook of the discipline. The paper contributes to the literature by addressing the issue of learning through an instrument-an issue not often dealt with in the literature on GIS and educational issues. Furthermore, the paper links theoretical discussions of how to study learning processes when using an instrument from other disciplines in the field of geography and thereby build a bridge between educational traditions within different areas of research.

The paper is organized as follows: first, we outline our notion of spatial thinking and GIS. Second, on the basis of the philosophy of technology, we unfold how GIS can be interpreted as an instrument for learning and outline the instrumental genesis approach to studying students' learning processes when using instruments. The main part of the paper then is a case study of how students are introduced to and learn GIS at an introductory course at the University of Copenhagen. Through the analysis, we reflect upon the students' learning strategies for creating a personal instrument, how the style of teaching modifies the creation of the personal instrument, and how it relates to the students' different learning strategies. On the basis of the case study, we further reflect upon how the use of GIS in learning to think spatially might influence students' spatial skills and hence the professional outlook of geography. Finally, we discuss the research implications of our study.

\section{Spatial Thinking and GIS}

Through time, geographers have used a variety of artefacts such as maps, globes and planimeters as professional tools for spatial thinking. Each of these artefacts has in one way or the other shaped our ways of being and becoming geographers. They have shaped not only how we learn but also what we learn. New types of artefacts are constantly introduced into the profession and some have more profound and persistent effects than others. One example of this is the introduction of GIS, which has its origin in the 1960s with the Canadian Geographic Information system developed for mapping purposes (Goodchild, 1995). Several definitions of GIS exist which have evolved in different fields and disciplines, from the toolbox-oriented definition given in Burrough (1986) to definitions concerned with the interpretation of GIS such as Kemp and Goodchild (1991) and Kemp et al. (1992) that focus on a distinction between learning about GIS and learning with GIS.

Although many definitions exist, most in one way or other identify GIS as a tool for collecting, managing, analysing and presenting spatial data. This is also true for the definition provided recently by the National Research Council:

Geographical Information Systems (GIS) is an integrated system of hardware, software, and procedures designed to support the collection, management, manipulation, analysis, modelling, and display of spatially referenced data about Earth's surface in order to solve complex planning and management problems (National Research Council, 2006, p. 18).

The use of GIS has increased in research and in education at geography departments worldwide in the last 30 years, and in recent years this process has accelerated. GIS had become more and more integrated into the field of geography, and this has given rise to discussions of whether GIS should be admitted as part of the intellectual core of geography (Sui, 1995; Drennon, 2005). However, these discussions have largely been bypassed by 
the real world integration of GIS in geography curricula and by pressure from job markets (Kemp et al., 1992).

There is no clear consensus about spatial thinking, and many related concepts are in use (Lee \& Bednarz, 2009). In practice within the field of geography, spatial thinking in one form or other underlies a significant amount of geographic learning such as the use of maps, graphs, images, diagrams, models and visualizations (Bednarz, 2007). According to Learning to Think Spatially, there are three types of spatial thinking: thinking in space, thinking about space and thinking with space (National Research Council, 2006). Thinking in space is used to perform actions and requires thinking in a real-world context, such as taking the bus to university, walking the dog or even packing a suitcase. Thinking about space is focused on a scientific understanding of the nature, structure and function of phenomena; for example the structure of the atom or the structure of the Earth. Thinking about space involves thinking about the ways in which the 'world' works. Thinking with space is the most abstract form of spatial thinking and deals with the conversion of some data relationship between objects into locations and, therefore, arrangements of the objects in a space (e.g. population pyramid). These three types of spatial thinking are highly interwoven. Thinking in space for instance promotes thinking about space, whereas the use of space as a cognitive strategy adds power and aids in thinking in and about space (Bednarz, 2007).

GIS have in various forms been linked to spatial thinking as discussed in the introduction. If we follow the definition of spatial thinking as mentioned above, the activity of learning GIS involves and develops all three types of spatial thinking. However, the focus is most often the abstract form of spatial thinking, which is to teach students to think with space. An example of how spatial thinking unfolds in relation to GIS is given in Figure 1. To undertake, read and understand the analysis in Figure 1, you need to be a spatial thinker. Being familiar with the rules of spatial thinking, you will be able to read the map and understand the analysis, but without these skills you may just see a picture with a circle and names on it. Furthermore, to analyse, communicate and judge the value of this, you must also use your spatial skills.

\section{GIS seen as an Instrument for becoming a Spatial Thinker}

An artefact such as GIS is not neutral. By being an instrument, it shapes our perception of the world. How and with what effect this shaping takes place is not explicit or shared common knowledge, but an integrated part of a geographer's experience of being a geographer. Säljö (2003) describes how both our thinking and our actions are closely related to the specific artefact and are deeply affected by the built-in resources of this artefact. He gives the example of the pocket diary:

We think in symbiosis with the pocket diary. We exchange meaning, content and sense between the user and the artifact in relation to reading and writing. We can metaphorically speaking park meaningful statements like information in that type of artefacts and call them to life again, when we need them (Säljö, 2003, p. 80, own translation).

He further points out that the technology behind common modern artefacts is often invisible and in fact not understandable by the user. Seen in this perspective, learning is about becoming able to use the cognitive resources as information, procedures and routines, which are implicit in the artefact (Säljö, 2003). 


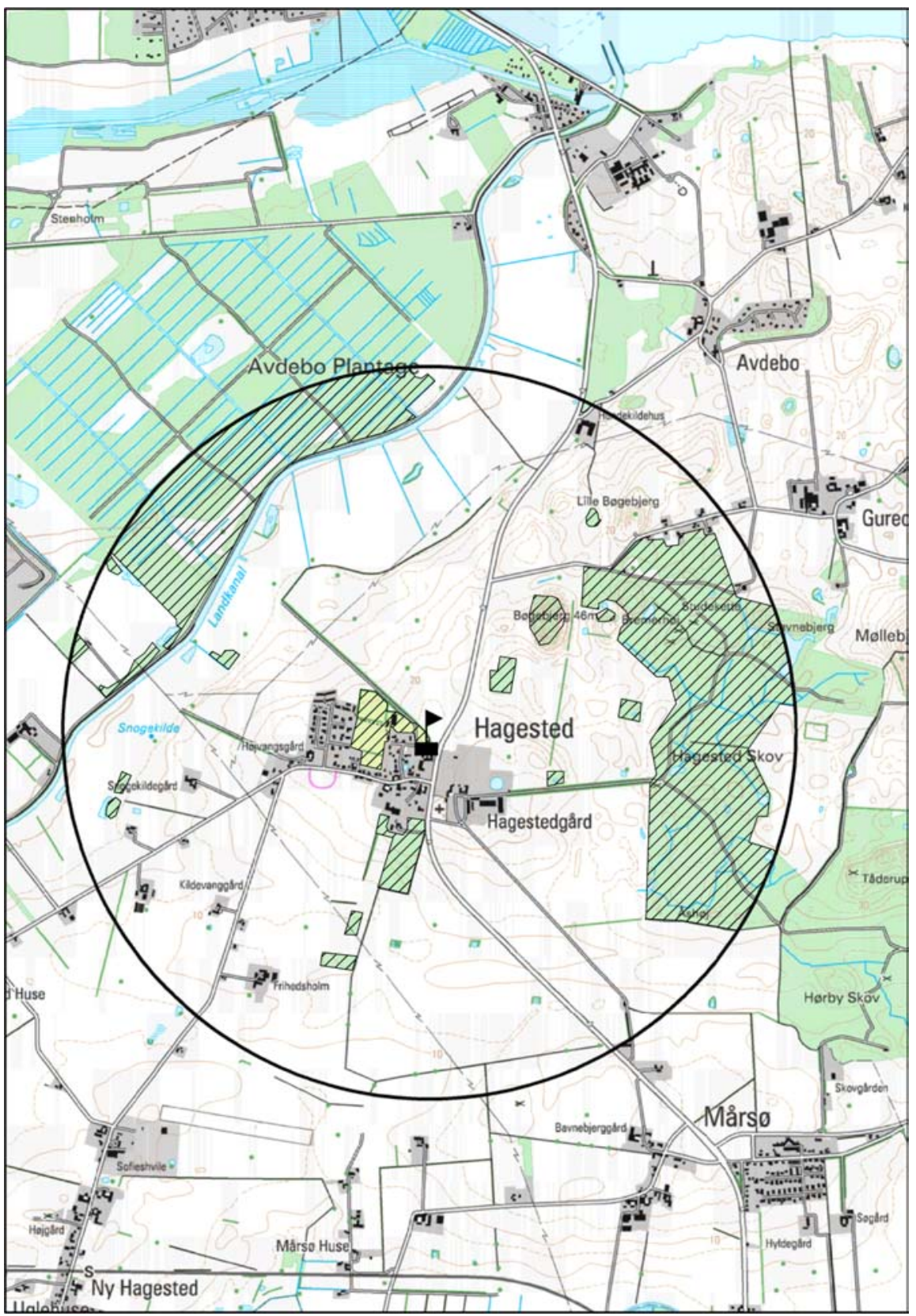

Figure 1. Spatial thinking within a GIS. Within Figure 1 is a digitalized 1:25.000 map of a rural area in Denmark. A point of interest is highlighted with a flag (a school) and the result of an analysis of the area of woodlands within a $1500 \mathrm{~m}$ radius from the school is shown. This analysis is made with the buffer-function within the GIS. This kind of analysis could be a result of the following exercise given to the students to train them in spatial thinking: Find the location and distance to the woodlands that is within reach of a bicycle-ride from the school of Hagested. 
The relation between knowledge and scientific instruments has been an issue in the philosophy of technology and to some extent also the philosophy of science during the past 30 years in what Ihde (1991, p. 45) terms "the 'school' of instrumental realists". He argues that "Instruments form the conditions for and are the mediators of much, if not all, current scientific knowledge. They are the concrete and material operators within scientific praxis." Instruments are thus an important part of scientific knowledge and hence, the education of future scientists. It should be noted that the philosophical stance of the instrumental realists is a particular form of realism in the philosophy of science. The instrumental realists hold that scientific instruments can provide access to phenomena in the world which are otherwise hidden from us. They are entity realists in that they hold that even if 'observations' from instruments cannot be observed in the traditional sense with the naked eye, and thus potentially can be misleading artefacts produced by the instruments or be mere theoretical entities, the 'observed' objects are regularly manipulated to produce new phenomena. When they are so, they argue, we must accept their existence (Ihde, 1991, part V).

A 'seeing as' metaphor is strongly present in Ihde's discussions of the role of instruments in science. Indeed, the notion of seeing is not merely a metaphor to Ihde; indeed, he argues that scientific observation is perception through the so-called embodiment of instruments:

Instruments extend the human senses, and in the context of early modern science, made its first distinctive embodiment as a thoroughly technologically embodied science possible. Galileo's use of the difficult and primitive telescope provided him with an 'artificial revelation' of phenomena never before seen nor suspected. Along with its use of a unique form of mathematization, early modern science was to henceforth differ from all its predecessors by being instrumentally embodied in technologies (Ihde, 1991, p. 74).

Ihde further argues that with some types of technology our relation is not to be seen as extensions of sensory-bodily capacities but, rather, as extensions of linguistic and interpretive capacities. He calls these hermeneutic relations:

In embodiment relations the technology-instrument—is taken into perceptual and bodily experience $[\ldots]$. The technology becomes a 'part' of my now extended bodily experience of the world. But in hermeneutic relations, the technology is much more 'text-like' and retains a sense of quasi-otherness not present in embodiment relations. The hermeneutic 'transparence' is thus like that of textual transparency (Ihde, 1991, p. 75).

To illustrate this, Ihde gives the example of computer printed data or a map as instruments with which we have hermeneutic relations. Hence, the GIS instrument will work for a geographer as a text works for literate persons. It is not the text which is the focus, but the content that is 'seen through' the text. In other words, you need to be able to look through the instrument (GIS) to be a competent spatial thinker.

Seen in this perspective, learning is about obtaining the necessary skills to become a 'trained scientific hermeneut' (Ihde, 1991, p. 131). It entails using the instrument to both 'write text' - to produce data, to 'read text' - in the form of output from the instrument, and in all other respects to learn to handle the instrument manually and intellectually in the 
scientific process. To understand how students learn to think spatially by using GIS, we, therefore, need to address the issue of the artefact as an instrument and its influence on learning.

\section{How to look into Learning to think Spatially with GIS}

To understand the process of how GIS become hermeneutic transparent for the student, we must first understand what happens in the process. Ihde (1991) uses Martin Heidegger's example of the use of a hammer:

So long as one is using the hammer within its work context, the hammer-as-object 'withdraws' and the context of relations of the work project may remain both transparent and familiar but tacit. But what happens if the hammer is missing, or is broken, or ceases to function? Its phenomenological transparency is then changed, it becomes opaque, and the hammer may become an 'object'. That is to say, as a result of withdrawal, the hammer, even if missing, becomes not the means of achieving the work but an obstacle to its attainment (Ihde, 1991, p. 54).

As GIS as an instrument is complex and far from as straightforward in use as a hammer, the students' first encounter with GIS is comparable to the broken hammer. The GIS instrument is opaque; it is the instrument itself rather than the spatial content that is in focus. Through a hermeneutical process, or learning process, the instrument is then to become transparent. This has been described by Heelan (1972):

Let us suppose that marks are discovered on clay tablets known to belong to an ancient but as yet undeciphered language. These marks are at first studied and compared as objects: the subject-object cut places them on the object side of the cut. Later, when fully deciphered, they are recognized as signs belonging to a natural or artificial language. When students of this language are sufficiently familiar with it, they can begin to read the signs for their meaning .... The signs, then, have come to be displaced to the subject side of the cut (Heelan, 1972, pp. 104-105).

Through education and through the continuous life-long learning of the researcher, the scientific object is then observed and studied 'directly' through the scientific instruments. The instrument becomes part of the subject because the object studied is not the scientific instrument, but the scientific object in focus. Heelan (1972) terms the process of the instrument shifting from the object side to the subject side of the subject-object cut a hermeneutical shift. In relation to GIS, we as professional GIS users re-experience this hermeneutical shift every time a new version is on the market; for instance the version ArcView 9.1, which had extensive changes. In such situations, we experience that the instrument is no longer transparent, and our attention is re-focused on the keys and functions that are now different. We become annoyed with having to spend time on finding out how to do the analysis we want to do-we are blinded by the instrument just like the students in their first encounter with GIS.

The theory of instrumental genesis, which has been developed within the field of educational research in mathematics (Guin \& Trouche, 1999; Trouche, 2004, 2005; Guin et al., 2005; Monaghan, 2005), can be used to study the hermeneutical shift in learning GIS 
in greater detail. The idea of instrumental genesis can be described as a process where an artefact such as GIS shifts from being an object/tool to being an instrument for the student, and the student then experience the hermeneutic shift of Heelan (1972). The process is complex and is: 'Linked to characteristics of the artefact (its potentialities and constraints) and to the subject's activity, her/his knowledge and former work methods' (Trouche, 2005, p. 144).

Within the instrument, the scholarly knowledge and the knowledge of how to use the artefact merges together. The GIS are the artefact, a material tool, while the instrument is a personal construction which develops continually, even for very experienced users (Winsløw, 2005). In relation to GIS, the idea of instrumental genesis can be described as a process, in which GIS as a physical artefact gradually becomes transparent and a personal instrument for the student.

According to the theory of instrumental genesis, the relationship between an artefact and a subject develops through two opposite processes of instrumentalization and instrumentation (Figure 2). Instrumentalization is directed towards the artefact, i.e. the subject forms usage schemes related to the artefact (artefact on the object side, opaque), whereas the instrumentation is directed from the artefact towards the subject, i.e. the student obtains experience from usage of it, which results in modification or creation of new personal schemes beyond the artefact (artefact on the subject side, transparent)—for instance, modified or new knowledge about geography. Instrumental genesis is the process in which the subject, through instrumentalization and instrumentation, builds an instrument to perform certain types of tasks (Trouche, 2005).

From the field of mathematical educational research, we know that teaching and teaching materials can, to some extent, support the development of instruments among students. A wide range of research studies have shown that the introduction of Computer Algebra Systems (CAS) in mathematics teaching changes not only the way students learn but also what they learn. For example, using CAS to differentiate $f(x)=x \sin x$ involves a totally different set of mathematical actions from what is required to differentiate this function using the standard paper-and-pencil algorithm (Monaghan, 2005). If we apply this knowledge to GIS and students' learning of spatial thinking, what is important is not

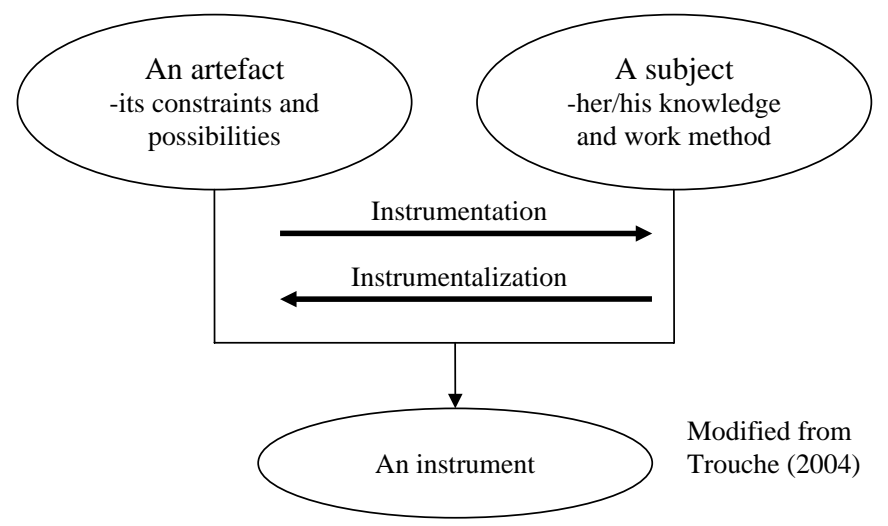

Figure 2. Creating an instrument from artefact to instrument. 
that the required actions are different from spatial thinking without GIS, but to understand what the use of GIS means both for the students' personal learning process and the tasks of teachers.

\section{An Empirical Study of Students' Development as Spatial Thinkers}

In this section, we empirically show which strategies students use to learn GIS, and further, how a certain teaching practice influences the students' process of becoming spatial thinkers. This is done by analysing the group of first-year geography students at the Department of Geography and Geology, University of Copenhagen, attending the course: GIS and Cartography.

Copenhagen University is a research intensive University with approximately 35000 students. The geography department is located at the Faculty of Science and is one out of three places you can study geography at university level in Denmark; GIS were introduced into the curriculum in the late 1980s. A course in 'Introduction to GIS' first served as a non-compulsory, technically oriented course at masters' level. Through the years, it has gradually been moved to bachelors' level. Finally, in 2002 it was placed as a mandatory introductory course for all first-year geography students at the University. The course (now named 'GIS and Cartography') gives the students an introduction and first-hand experience with GIS and is supplemented by six elective GIS courses placed later in the geography curriculum. This change also reflects the increasingly important role GIS play in the international and national communities of geographers.

The students enter the study of geography with a broad range of educational backgrounds and there are requirements of mathematical skills. All of the students have been trained in spatial thinking through their high school; however, only very few have specific experience with GIS when they enter university. A recent study has shown that the students are remarkably identical when it comes to economic status, ethnicity and family educational background, as well as region of origin (Lorenzen, 2010). Other aspects, such as the students' different IT skills, may have influenced the students' strategies. This has not been systematically tested in the present study, but could be so in the future to explore further why some students prefer certain strategies when approaching GIS.

\section{Material and Methods}

'GIS and cartography' is attended by just under 100 first-year undergraduate geography students each year. In lectures, central elements of GIS and cartography are introduced. The focus is on how different abstractions of the world can be represented within GIS through the use of different data models. This is combined with hands-on laboratory classes in which various themes of human and physical geography are treated. At the end of the course, students' theoretical knowledge of GIS and cartography is assessed in a written exam.

The course runs for 9 weeks and consists of 2 weekly lectures (each of $45 \mathrm{~min}$ ) plus 2 weekly, 2-h computer laboratory classes in ArcGIS, version 9.1 (students are divided into four groups of separate laboratory classes). The laboratory classes, which are given by the lecturers of the course, start by introducing the day's topic. Afterwards the students work in pairs with the GIS using a 'manual' containing practical instructions and exercises. The lecturer is present throughout the classes and helps solve problems. The students also use 
GIS in their parallel introductory course in human and physical geography as well as in several later courses in both human and physical geography. In these parallel and later classes the teaching and learning of GIS tends to be more and more project oriented.

In the academic year 2004-2005, 79 students were enrolled in the course in GIS and cartography. To study the students' learning experience of GIS, we collected and analysed the following material concerning this particular group of students and their experiences of learning GIS:

- Classroom observations (in 25 laboratory classes and 3 lectures).

- Qualitative interviews with teachers in 'GIS and cartography' (three interviews).

- Qualitative single and group interviews with students (six interviews with a total of nine students, during the course and eight interviews with a total of 15 students, after examination).

- Questionnaire (49 students answered the scheme equal to a response rate of 62 per cent: 27 women and 22 men. Not all students answered all questions, so exact number of answers are given in each figure shown). The questions given in the questionnaire were based on classroom observations and interviews with students as well as interviews with the teachers. It consists of both open and closed questions concerning the students' degree of participation, their experiences within the different teaching formats (laboratories, lectures and assignments), their degree of agreement with a number of statements concerning their learning practice, whose formulation was based on information from the qualitative interviews and open questions inviting them to describe their learning process. The questionnaire was electronic and handled through the university's administrative system. Mails informing about the questionnaire were sent on the day of the exam and flyers were handed out when students left the exam room. Reminders were given and the questionnaire was open for input for a 3-week period.

The methodology employed in this research is within the tradition of in-depth ethnographic work within cultural geography with a focus on qualitative and discursive research methods (e.g. Crang, 1998; Hoggart et al., 2002; Pryke et al., 2003). It has clear relations with phenomenographic studies as it focuses on the experiences of the students (e.g. Marton \& Säljö, 1976a, 1976b). But in contrast to phenomenographic studies, our study does not have an outcome space consisting of categories of description which are logically and/or hierarchically interrelated.

The outcome space of the analysis in this paper is a typology of individuals' conceptions of their learning process in creating a personal instrument. These conceptions can vary over time and also entertain distinct conceptualizations at the same time in distinct learning situations. The developed typology is, therefore, situated within the concrete teaching and learning context, although students may come to class with individual preferences for specific approaches to learning. These preferences may or may not be realized in practice, depending on the teaching context. This is to say that we, as do Biggs and Tang (2007), take a middle position in the discussion of learning styles, in which students are either assumed to always prefer the same approach or learning approaches in which students' approaches are taken to vary fully depending on the context. The way students shape their personal instrument through their learning strategies we see as flexible and constantly under construction and re-construction by the individual student in relation to the teaching practice she/he meets, both in the different courses and at the university as a whole. 
To take into account this dynamic nature of learning, the typology was developed on the basis of the students' answers to an open question in the questionnaire rather than preclassified types asked for in a questionnaire. The question was 'How do you go about learning GIS? Please describe what you actually do, rather than what you think you ought to do.' In structuring and analysing the data, all written answers to this question were read and re-read in a process of going back and forward between the written answers and the analytical question: what learning strategies do the students use to learn GIS. This process resulted in the developed typology. In the process of constructing the typology, information from the interviews with students and classroom observations was used to shape the identified types of learning strategies. This method of analysis resembles thematic analysis described by Braun and Clarke (2006).

\section{The Students' Learning Strategies for creating their Personal Instrument}

We found that the students used five different strategies in their learning process to develop their personal instrument during the 'Introduction to GIS and cartography' course. The described strategies are the students' preferred strategies used in this specific learning situation and are shown in Figure 3.

Three learning strategies dominate the picture, namely types A, B and C, whereas types $\mathrm{D}$ and $\mathrm{E}$ were rare. Type A describes students who prioritize the task, i.e. they go through all the literature, exercises and lectures; type $\mathrm{B}$ refers to students who prioritize understanding in their approach to GIS and type $\mathrm{C}$ describes students who prefer to 'play around' with the GIS to learn. Type D students indicate that they learn GIS when they use it in the adjacent course in human and physical geography. Finally, type E students question whether they have learned GIS at all.

Examples of the three main learning strategies:

Type A student: "I attended the lectures, wrote notes and printed out the hand-outs. Before the final exam I read all the assignments including the hand-outs. I made notes so I had an overview of the different concepts and expressions. I wrote down where in the assignments the different concepts were defined. I marked the text and made tables of content to the texts for which we did not receive tables of content.

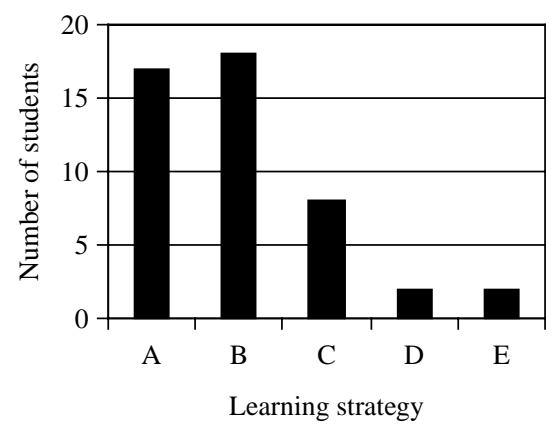
A: Prioritize "doing the task"
B: Focus on understanding
C: Play with the GIS-programme
D: Combine it with other subjects
E: Question whether they have learned GIS

Figure 3. Students' learning strategies for creating a personal instrument $(N=47$, three students have given two strategies, both strategies are included). 
I put the texts and notes in a ring-binder organized in accordance with the lectures. I attended all the classroom exercises and the ones that we didn't finish in class we made sure we finished later."

Type B student: "I went to both the lectures and the labs. In the labs I focused on understanding what we where doing and not just going along (and finishing the exercise). I read all the course assignments, but only once.... I sat down in the exam preparation period and discussed different topics with the other students."

Type C student: "I sat many hours with ArcMap/ArcCatalog (the computer program ArcGIS) both at home and in the labs. This has given me a pretty good overview to understand what the lectures were about."

These learning strategies show that the students have different ways of developing their personal instrument and, as will be discussed later, the form of teaching in use influences this development in different ways. Type A students can be said to have a focus on intrumentalization rather than instrumentation, type B students have focus vice versa that is a focus on instrumentation rather than instrumentalization, whereas the focus of the $\mathrm{C}$ students may vary.

\section{The Influence of Teaching on Students' Route to becoming Spatial Thinkers}

Within the theory of instrumental genesis, it is a central idea that teaching and teaching material can, to some extent, support the students' development of personal instruments (e.g. Guin \& Trouche, 1999). The external support or direction of students' instrumental genesis is called orchestration. Different types of orchestration have been described and developed in the context of CAS (Trouche, 2004).

In our study, it was evident that the type of orchestration-in this case the layout of the course and the teaching method used-had implications for the learning process. As mentioned, the experimental part of the course is organized around 2 weekly, 2-h computer laboratory classes, which are the focus in the following. The laboratory classes use a 'manual' containing practical instructions and exercises. Especially the orchestration presented by the manual had profound effects on the students' instrumental genesis. The manual can be described as a cookbook with recipe-like text that must be followed by the students to do the assignments. The following is a typical quote from the exercise manual:

Choose Spatial Analyst $\rightarrow$ Reclassify, put Input-raster $=$ dist_water, press Classify, press the Method-arrow and choose Equal Interval, press the Classes-arrow and enter 8 and press OK. Press the first New Values record in the Reclassify-window and replace the value 1 by 8 , the value 2 by 7 and so on. Leave the field No Data untouched. Press OK and see the result which is placed in a new grid file with the name Reclass of dist_water.

This kind of manual must be followed closely to obtain a successful outcome, and does not encourage the students to explore the software as also found by Meitner et al. (2005). Thus, it does not support the students in constructing their own perception of the spatial issues dealt with in the specific exercise. Rather it directs the student's attention towards 
GIS as an object, and hence it may not be very helpful for the students in the instrumentation process.

The orchestration created different forms of work among the students. Some students just followed the instructions and did not link their activities with their theoretical knowledge of spatial issues at first. One of the students expresses it this way in the qualitative interview:

It is just so schematically and pedagogically put together that you are able to put yourself on autopilot-that's at least how we have experienced it - and we sit and are almost—not falling asleep, but you get very tired in your head because-and now it is very harshly said-but you just put yourself on autopilot and just do [presses with the fingers on the table] what is said in the papers [exercise manual].

Other students reported that they actively opposed this type of practice and tried to link their interaction in the exercise to their theoretical understanding, as expressed by another student:

I often stop during the GIS-exercise and think through what I just did on the computer screen.

On the basis of the students' answers in the questionnaire, we found that these different types of responses to the teaching orchestration were related in a complex pattern to the learning strategies of the students as elaborated as follows. It appears that students with different learning strategies tend to react differently to the following two quotes given in the questionnaire: "It is important for me that I am forced to think when I do the GISexercises" and "I often stop during the GIS-exercise and think through what I just did on the computer screen."

A majority of students consider it important that they are forced to think when they work with the GIS exercises. This tendency is strongest among the type A students (who prioritize 'doing the task') where 65 per cent of the students agree with the quote. For type B students (who prioritize understanding), 42 per cent agree that it is important, whereas 25 per cent of Type $\mathrm{C}$ students (who prefer playing with the GIS) agree. These numbers indicate that A students who do not prioritize understanding as high as B students find it more important to be forced to think when they work. This indicates that A students despite prioritizing getting the work done have a high awareness of the benefits of reflecting through the exercise. Their request of being forced to think during the GIS exercises can be linked to the fact that they do not by themselves practise this as revealed by their answers to the second quote. Here, only 12 per cent of type A students agree that they often stop during the GIS exercise and think through what they just did on the computer. Instead, type A students stick with the cookbook 'recipe' to get the job done. Otherwise, type B students (those who have an understanding oriented approach) do not to the same degree find it important to be forced to think during the GIS exercises. This can be explained by the fact that more of these students practise by themselves: 37 per cent of type B students agree with the second quote that they often stop and think through what they just did in the exercise. This tells us that type B students tend to oppose the teaching orchestration with the manual: they actively stop to reflect during the exercise. Perhaps, surprising at first, type C students (who play with the GIS as a strategy of learning) seem to adapt to the orchestration by running through the manual like a cookbook recipe (13 per 
cent of type $\mathrm{C}$ students agree on the second quote and 25 per cent find it important to be forced to think during the GIS exercise). But when asked how they have learned GIS, they tell us about situations in which they have 'played' with the GIS after class. From classroom observations and interviews, we get the impression that some of the type $\mathrm{C}$ students use the manual quite systematically just as type A students, but at the same time they perceive this as a kind of pre-understanding. Later on, they go home and play with the computer program to gain a deeper understanding. It should be noted that all students have the opportunity to freely install the GIS software at their own computer and due to the Danish free education system and state-provided financial support, all students should be able to have computer facilities at home.

In relation to developing the students' spatial thinking, the orchestration with the manual further seems to focus students' attention onto the computer interface in classroom, thereby hindering discussions of geographical issues related to spatial thinking. By observing four laboratory classes, we found that 81 per cent (total number of questions: 105) of student questions directed at the instructor dealt with technical issues of the software or imprecise guidance in the manual (the instrumentalization process). For example:

Why can I not save my data?

(tries to save on the G-drive instead of the I-drive)

How do I install the A/L button?

(the area and length facility, A/L is not standard and must be installed separately).

Only 19 per cent of the questions dealt with conceptual questions regarding spatial perception (thus supporting the instrumentation process). These are questions such as

I can't make a scale and north arrow, why?

(It is not possible because the students are working in the system 34, a Danish technical version. A discussion begins on different representation systems).

On the basis of classroom observations and registration of dialogue between the teacher and the students, we found that the students' work with the manual redirecting the students' attention towards the computer interface, and hence the artefact as an object. The discussions between the students and the instructor are mainly concerned with the instrumentalization process, whereas the construction of GIS as a personal instrument through the instrumentation process is vaguely supported. Furthermore, the interaction with the manual draws attention away from the geographical issues that the students are supposed to see 'through' the GIS. In this way, the style of teaching affects the learning strategy of the students as they are urged to use the cookbook recipe strategy and as attention is constantly shifted to the GIS instrument itself, instead of the content that can be seen through it. The use of the manual thus seems to affect the students' instrumental genesis in a partly unconstructive way. In their learning strategy, type A students follow the orchestrated teaching and are thereby left with a low chance of creating a strong personal instrument. Type B and C students, on the other hand, have different strategies for dealing with the teaching orchestration to develop their personal instrument: type B students stop during their work with the manual and reflect on what they are doing in class while type $\mathrm{C}$ students play with the GIS at home and create their personal instrument outside the teaching environment. 
These last two types of learning strategies result in personal instruments for the student, despite the teaching orchestration.

In the data, the following gender differences were found (Figure 4). Slightly more men than women prioritize 'doing the task' (type A). More distinctly, a larger number of women than men seek understanding (type B), whereas more men than women play with the ArcGIS program (type C) to learn GIS. If we understand type $\mathrm{C}$ as a 'mastering' strategy or competence strategy in which the students have a somewhat independent reaction to the teaching environment, we can see that the two types of students who oppose the teaching orchestration (type B and C) fall into two categories with the female students being more compliant within the given teaching environment and the male students being more autonomous in their learning strategy. This is similar to results of gender differences found within physics education (Hasse, 2002), in which male students are found to be more prone towards 'playing' with the laboratory settings beyond the manual prescriptions, whereas the female students stick more consciously to the manual.

\section{Reflections on the use of GIS and the Professional Outlook of Geographers}

In this section, we argue that the now widespread use of GIS in the education of future geographers has created a need for reflection within the discipline. We recognize that the map (paper or digital) plays a central role in spatial thinking and has and still have a major

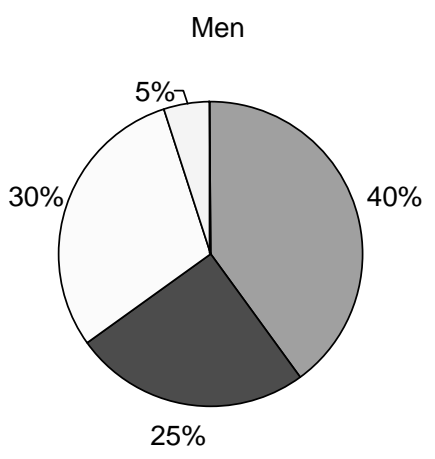

$\square$ A: Prioritize "doing the task"

B: Focus on understanding

$\square$ C: Play with the GIS-programme

$\square$ D: Combine it with other subjects

E: Question whether they have learned GIS

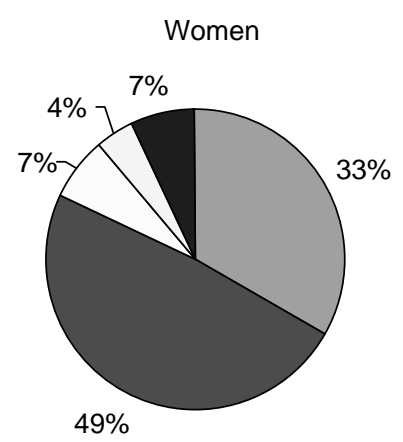

$\square$ A: Prioritize "doing the task"
$\square$ B: Focus on understanding
$\square$ C: Play with the GIS-programme
$\square$ D: Combine it with other subjects
$\square$ E: Question whether they have learned GIS

Figure 4. Students' learning strategies-men and women $(N=47$, three students have given two strategies, both strategies are included). 
influence on how we think, apply, act and define ourselves as geographers. Our claim is that using GIS to learn to think spatially is a specific way of seeing the world that further modifies and transforms the professional outlook of spatial thinking for both students and teachers/researchers and, therefore, needs attention.

First, we need to define what we mean by professional outlook. Kuhn (1970) suggests that knowledge of the rules of a discipline and of important exemplars provides a person with an outlook and an ability to act within that discipline. On the basis of this, Christiansen (2004, p. 19) defines professional outlook within a discipline as "a personal way of seeing the phenomena and situations of relevance to the profession." Hence, professional outlooks are outlooks from a particular place or perhaps from within a certain discourse of what it means to be an educated person within a particular profession. Christiansen further describes student's learning: "Understanding the fundamental rules of a scientific discipline may provide $[\ldots]$ an optic or outlook through which hypothetical situations may be envisioned by means of the rules of the discipline and the student's imagination" (Christiansen, 2004, p. 24). In this perspective, he further finds that the purpose of higher education is a matter of providing the students with professional outlooks in order for them to learn a process of discernment, and teaching becomes a question of helping students to learn to see 'through the eyes of the discipline'.

The professional outlook of a discipline is continuously contested, recreated and developed, and in these processes new instruments such as GIS play important roles. As we have shown in the analysis, students have different strategies for creating a personal instrument of spatial thinking when they are learning GIS. We have also argued in the paper that the use of instruments is not neutral and it influences the way things are perceived and understood. However, to show empirically how GIS alter the way we as geographers think spatially, and thereby transform and modify the professional outlook of geographers, is not an easy task. However, by letting the students elaborate on how they use GIS, some insights can be made. In the following quote, a student reflects on how she learned a particular task within the GIS:

You have a road and must calculate the area that will be affected by noise in a zone 200 meters from the road. Then I think in concrete GIS: select residence and ... then these words and that way to do it, and the structure you have trained through the laboratory classes.... The way you have learned to think is that you choose some things and then they must be selected, overlaid or ... make buffers. Buffer gives sense because ... if you just think buffer is the straight distance from a point, then it makes no sense... you see that picture of a circle around a point for instance and then it makes sense to a start and then you can use the theory to explain why it looks like it does.

This answer indicates that the interaction with the GIS influences the student's knowledge of spatial configuration. She thinks in terms of the functions within the GIS when she creates spatial meaning. We interpret this as an indication of a change of the professional outlook created when educating geographers using GIS. In this example, the GIS interact with geography knowledge in the process of instrumental genesis and influence spatial thinking. Yet, we need more longitudinal observational studies of the students' interaction with GIS to understand what it means for students to use GIS in a wider sense for their thinking and understanding of geography and further, to inform our knowledge of how spatial thinking and thereby the professional outlook of geographers is modified and transformed. 


\section{Conclusion}

The professional outlook of a discipline-perceived as the ability to act within a discipline-is continuously created, recreated and in these processes contested and changed. In this development, instruments for doing the profession such as GIS in the field of geography play an important role because they are not neutral agents. GIS are a physical artefact that gradually becomes transparent and a personal instrument for the learner through the process of instrumental genesis. With the personal instrument, the scholarly knowledge (geography) and the knowledge of how to use the artefact (GIS) merges together. The use of GIS in geography will inevitably change the way we as geographers think spatially (in this paper illustrated by the student quote about solving a particular task). As GIS have become more and more widespread in the education of geographers, we, therefore, need to address not only the skills of students as spatial thinkers, but also the learning processes leading students to become spatial thinkers.

In a small empirical study of how students learn GIS at the University of Copenhagen, we have shown that the use of GIS is not neutral and it influences the way students perceive and understand geographical issues. Also we have shown that students have different strategies for creating their personal instrument for spatial thinking when they are learning GIS. Importantly, it was further found that the chosen teaching orchestration with a cookbooklike manual had different effects on the learning strategies of the students in their process of creating personal instruments. Type A students follow the orchestrated teaching and are left with a low chance of creating a strong personal instrument because they follow the cookbook recipe quite meticulously, causing their attention to be constantly refocused to the GIS instrument itself, instead of the result of the geographical analysis performed. Type $\mathrm{B}$ and $\mathrm{C}$ students, on the other hand, have their own strategies for dealing with the teaching orchestration to develop their personal instrument: type B students stop and reflect during their work with the manual, and type $\mathrm{C}$ students play with GIS at home and create their personal instrument outside the teaching environment. These last two types of learning strategies can be interpreted as a case of the students creating their personal instruments and becoming spatial thinkers despite the teaching orchestration.

The implications of these findings are threefold. First, in relation to education it is important to support the students in their process of making GIS transparent and thereby a personal instrument for spatial thinking. To understand these learning processes, we find that the theory of instrumental genesis developed in the field of mathematical educational research can be a valuable research framework. The theory has proven valuable for understanding students' use of calculators to solve mathematical problems and given rise to discussions of teaching practice within the mathematical community. We find that the theory could contribute equally to a research focus on the learning processes among students when learning GIS and give valuable findings for our geographical teaching practice.

Second, from our small empirical study, it seems that the rather 'traditional' cookbook manual used in this course is not the best way to support the learning processes of students in their first meeting with GIS. Often it is argued in favour of the use of a cookbook manual that students must have a basic knowledge of GIS before they can manage to do more project-based work. However, our results show that some students actually learn without the manual using other strategies to comprehend and develop their spatial thinking skills. The students who follow the manual meticulously state that they are almost on autopilot in the learning process and were surprised how little they could remember when we tested 
them (Madsen \& Holm, 2006). These results are further supported by another study in which we interviewed the students later on in their study in another GIS course. Many students regardless of their former learning strategy stated that their GIS skills were relatively low entering the later course (Madsen et al., 2009). We found that the cookbook style manual seems to focus the students' attention to the GIS tool itself, leaving reflections of the geography analysis untouched. Yet, one could argue that this is an introductory course in which students first have to learn basic technical skills and, therefore, need to focus on the GIS instrument; later on they can handle learning without a cookbook-like manual. This kind of argument can be based on the distinction in the literature between learning about GIS (deals with geographical data handling or geographical information management) and learning with GIS (seeks geographic knowledge and geographic intelligence) (Kemp \& Goodchild, 1991; Rød et al., 2010). This distinction seems to imply that students need to learn about GIS before they can learn with GIS (e.g. Andersland, 2011). Such arguments legitimate using a cookbook manual in introductory courses in GIS. However, the theory of instrumental genesis tells us that this is not how learning occurs, instead mastering a geographical analysis within the GIS is learnt when scholarly knowledge and understanding of how to use the artefact merges together and the latter becomes transparent for the learner. This is a truly complex issue and the results from our small empirical study only give us a hint about the relations. Studies of learning processes with other teaching orchestrations would be valuable. This might include manuals trying to generate geographical thinking by asking students to solve problems by applying what they have just learnt as they come to the end of each 'recipe', or using a combination of questions and a suitable GIS reference book for introductory levels.

Third, on the basis of literature from philosophy of science and by giving an example of how a student uses the terminology of GIS to support him/her in his/her spatial thinking process, we argue how GIS gradually alter the professional outlook of being a geographer and the way geographers think spatially. This constant creation and re-creation of the way we interpret the spatial world linked to the instruments we use needs attention within the discipline. We suggest that the theory of instrumental genesis can give us research ideas of how to address this.

\section{Acknowledgements}

First, we thank all the first-year students at the Department of Geography and Geology, University of Copenhagen, in the academic year 2005-2006 for their time and effort in trying to let us understand their learning processes and perceptions of the world of GIS. We thank the team of teachers at the GIS and cartography course for their enthusiasm and willingness to show and discuss their teaching practice with us. This work has been possible through a university teaching development project financed by the Faculty of Science, University of Copenhagen. The entire teaching development project is described in detail in Madsen and Holm (2006). Furthermore, we wish to thank a number of referees for their valuable comments that improved the paper significantly.

\section{References}

Albert, W. S. \& Golledge, R. G. (1996) The use of spatial cognitive abilities in geographic information systems: The map overlay operation, Transactions in GIS, 3(1), pp. 7-21.

Andersland, S. (2011) GIS I geografifaget på ungdomstrinnet, fagdidaktiske perspektiver på å lære om og med GIS, Doktoravhandlinger ved NTNU, p. 12. 
Bednarz, S. (2007) Mapping the way forward in an uncertain world: Spatial thinking and geography, in: S. Catling \& E. Taylor (Eds) Changing Geographies: Innovative Curricula (Proceedings of the London Conference) pp. 13-26 (London: Herodot and International Geographical Union, Commission for Geographical Education).

Biggs, J. \& Tang, C. (2007) Teaching for Quality Learning at University, 3rd edn (New York: Open University Press).

Braun, V. \& Clarke, V. (2006) Using thematic analysis in psychology, Qualitative Research in Psychology, 3 , pp. $77-101$.

Burrough, P. A. (1986) Principles of Geographical Information Systems for Land Resources Assessment (Oxford: Clarendon Press).

Catling, S. \& Taylor, E. (Eds) (2007) Changing Geographies: Innovative Curricula (London: Herodot and International Geographical Union, Commission for Geographical Education).

Christiansen, F. V. (2004) Professional outlooks in Science and Engineering, Unpublished PhD-thesis, The Technical University of Denmark.

Crang, M. (1998) Cultural Geography (London: Routledge).

Deadman, P., Hall, G. B., Elliot, E. \& Dudycha, D. (2000) Interactive GIS instruction using a multimedia classroom, Journal of Geography in Higher Education, 24(3), pp. 365-380.

Drennon, C. (2005) Teaching geographic information systems in a problem-based learning environment, Journal of Geography in Higher Education, 29(3), pp. 385-402.

Goodchild, M. F. (1995) Geographic information systems and geographic research, in: J. Pickles (Ed.) Ground Truth: The Social Implications of Geographic Information Systems (New York: Guilford Press).

Guin, D. \& Trouche, L. (1999) The complex process of converting tools into mathematical instruments: The case of calculators, International Journal of Computers for Mathematical Learning, 3(3), pp. 195-227.

Guin, D., Ruthven, K. \& Trouche, L. (2005) The Didactical Challenge of Symbolic Calculators: Turning a Computational Device into a Mathematical Instrument (Dordrecht: Springer Science).

Hall-Wallace, M. K. \& McAuliffe, C. M. (2002) Design, implementation, and evaluation of GIS-based learning materials in an introductory geosciences, Journal of Geoscience Education, 50(1), pp. 5-14.

Hasse, C. (2002) Kultur i bevagelse-fra deltagerobservatoin til kulturanalyse-i det fysiske rum [Culture on the move-from participant observation to cultural analysis-in the physical space] (Frederiksberg: Samfundslitteratur).

Heelan, P. A. (1972) Hermeneutics of experimental science in the context of the life-world, Philosophia Matematica, 9(2), pp. 101-144.

Hoggart, K., Lees, L. \& Davies, A. (2002) Researching Human Geography (New York: Oxford University Press).

Ihde, D. (1991) Instrumental Realism: The Interface between Philosophy of Science and Philosophy of Technology (Bloomington, IN: Indiana University Press).

Kemp, K. K. \& Goodchild, M. F. (1991) Developing a curriculum in geographic information systems: The national center for geographic information and analysis core project, Journal of Geography in Higher Education, 15(2), pp. 123-134.

Kemp, K., Goodchild, M. \& Dodson, R. (1992) Teaching GIS in Geography, The Professional Geographer, 44(2), pp. 181-191.

Kuhn, T. S. (1970) The Structure of Scientific Revolutions, 2nd edn (Chicago, IL: University of Chicago Press).

Lee, J. \& Bednarz, R. (2009) Effect of GIS learning on spatial thinking, Journal of Geography in Higher Education, 33(2), pp. 183-198.

Lloyd, W. J. (2001) Integrating GIS into the undergraduate learning environment, Journal of Geography, 100(5), pp. $158-163$.

Lorenzen, P. (2010) Hvem er de nye studenter? Baggrund, interesse \& uddannelsesstrategi-en studiestartsundersøgelse på Biologi og Geografi \& Geoinformatik ved Det Naturvidenskabelige Fakultet, Københavns Universitet, Unpublished masters thesis, Copenhagen University, Specialerapport, IND's Studenterserie nr. 15 January 2010. Available at http://www.ind.ku.dk/publikationer/studenterserien/ studenterserie15/ (accessed January 2010).

MacEachren, A. M. (2004) How Maps Work, Representation, Visualization, and Design (New York: Guilford Press).

Madsen, L. M. \& Holm, C. (2006) GIS og Kartografi—et kursus om mere end kort [GIS and cartography-a course on more than maps] (Copenhagen: Department for Science Education, University of Copenhagen). 
Madsen, L. M., Christiansen, F. V. \& Rump, C. (2009) Development of personal desiderata while learning GIS, in: A. Bisel \& M. U. Garib (Eds) Proceedings of Frontiers in Science Education Research, Farmagusta, Cyprus, 22-24 March, pp. 441-450 (Famagusta: Eastern Mediterranean University Press).

Marton, F. \& Säljö, R. (1976a) On qualitative differences in learning I-outcomes and process, British Journal of Educational Psychology, 46, pp. 4-11.

Marton, F. \& Säljö, R. (1976b) On qualitative differences in learning II—outcome as a function of the learner's conception of the task, British Journal of Educational Psychology, 46, pp. 115-127.

Meitner, M. J., Gonzales, J., Gandy, R. \& Maedel, J. (2005) Critical thinking, knowledge retention and strife: Reflections on active-learning techniques. Paper presented at the ESRI Education Users Conference, San Diego, CA, July.

Monaghan, J. (2005) Computer algebra, instrumentation and the anthropological approach. Paper presented at the 4th CAME Symposium. Available at http://www.lonklab.ac.uk/came/events/came4/ (accessed December 2006).

National Research Council (2006) Learning to Think Spatially: GIS as a Support System in the K-12 Curriculum (Washington, DC: National Academies Press).

Pryke, M., Rose, G. \& Whatmore, S. (Eds) (2003) Using Social Theory, Thinking Through Research (London: Sage Publications).

Rød, J. K., Larsen, W. \& Nilsen, E. (2010) Learning geography with GIS: integrating GIS into upper secondary school geography curricular, Norwegian Journal of Geography, 64(1), pp. 21-35.

Sui, D. (1995) A pedagogic framework to link GIS to the intellectual core of Geography, The Journal of Geography, 94(6), pp. 578-591.

Summerby-Murray, R. (2001) Analysing heritage landscapes with historical GIS: Contributions from problem-based inquiry and constructivist pedagogy, Journal of Geography in Higher Education, 25(1), pp. $37-52$.

Säljö, R. (2003) Laring i praksis—et sociokulturelt perspektiv [Learning in practice—a sociocultural perspective] (Copenhagen: Hans Reitzels).

Trouche, L. (2004) Managing the complexity of human/machine interactions in computerized learning environments: Guiding students' command process through instrumental orchestrations, International Journal of Computers for Mathematical Learning, 9(3), pp. 281-307.

Trouche, L. (2005) An instrumental approach to mathematics learning in symbolic calculator environments, in: D. Guin, K. Ruthven \& L. Trouche (Eds) The Didactical Challenges of Symbolic Calculators: Turning a Computational Device into a Mathematical Instrument, pp. 137-162 (Dordrecht: Springer Science).

Verbeek, P. P. (2000) What Things Do, Philosophical Reflections on Technology, Agency and Design (Amsterdam: The Pennsylvania State University Press).

Winsløw, C. (2005) Didaktiske Elementer-en indføring i naturfagenes og matematikkens didaktik [Didactic elements - an introduction to the didactics of science and mathematics] (Copenhagen: Center for Naturfagenes Didaktik, Københavns Universitet).

Zerger, A., Bishop, I. D., Escobar, F. \& Hunter, G. J. (2002) A self-learning multimedia approach for enriching GIS education, Journal of Geography in Higher Education, 26(1), pp. 67-80. 